Available online at

http://journal.ugm.ac.id/ifnp

DOI: http://doi.org/10.22146/ifnp.33400
INDONESIAN FOOD AND NUTRITION PROCRESS

\title{
Effect of Atmospheric Packaging Method on Quality of Packaged Cooked IR 64 Rice (Oryza sativa L. indica)
}

\author{
Anggita Nugrahanto ${ }^{1)}$, Supriyadi ${ }^{1)}$, Yudi Pranoto ${ }^{1)^{*}}$ \\ 1)Food and Technology Department, Faculty of Agricultural Technology, Gadjah Mada \\ University, Yogyakarta, Indonesia \\ *Corresponding author’s email address: pranoto@ugm.ac.id
}

Received 15 March 2018; Accepted 30 June 2018; Published Online 30 June 2018

\begin{abstract}
Rice is considered as staple food that consumed in the form of steamed rice. Due to the emergency condition, like volcano eruption or flood, the availability and accessibility might be a serious problem. Therefore, a ready-to-eat rice is necessary. It would need a design processing condition to produce practical cooked rice in more economically packaging with different method.

Normal packaging and vacuum packaging of cooked rice followed by steaming for 60 minutes was conducted in this study. Two different storage temperatures include cold and room storage in day $0,1,4$, and 7 was used to evaluate. The result showed that vacuum packaging gave better reduction in microbial parameter. However, panelist gave same preference in both normal and vacuum packaged cooked rice. Overall, cold stored-packaged cooked rice gave better quality than room stored-packaged cooked rice, especially in microbial parameter. Thus, combination of vacuum packaging and cold storing could be an alternative way to produce cooked rice which can be consumed in difficult condition.
\end{abstract}

Keywords: Cooked rice; packaged cooked rice product; packaging methods; vacuum packaging

\section{Introduction}

Indonesia has a high potential of disaster (Association of Indonesian Environmental Observers, 2015) like earthquake, eruption, tsunami, flood, etc (National Coordination Agency, 2002). That disaster causes a lot of victim, in 2010 until 2014, there are 1.699.247 victims, 1.001.662 refugee (Gaffar, 2015). During refuge, a lot of food aid for the victims is instant noodle and rice. In emergency condition several food supplies such as instant noodle, rice, and else, cannot be prepared well because there are lack of potable water, fuel and cooking set (Daniel, 2014). Commonly rice is cooked by rice cooker because this way is the easiest and simplest way in cooking rice (Marsudi, 1984).

Storage of cooked rice in rice cooker for periods can increase microbial total in cooked rice (Sari et al, 2012). Therefore, innovation about cooked rice products is needed for maintaining microbial quality of cooked rice. By the presence of innovative cooked rice product, it is highly expected to reduce consumption of fuels, time and energy. According to Billiris et al. (2012) the suitable rice:water ratio could be reduced fuel consumption in cooking rice. Suitable 
rice:water ratio can be maximized by increasing temperature of processing in terms cooking temperature (Winarno, 1992).

One of the commercial cooked rice product is ready-to-eat rice in Korea and Japan. According to Lee (2006), the product has reached comercial value of 300 million dollar. Hence, study about cooked rice product is promising in food technology. Byun et al. (2010) showed that no significantly different in organic and inorganic retort pouch packaging toward ready-to-eat cooked rice product shelf-life, so it can be said that organic material can be used to an alternative in retort pouch material packaging. In another study, Jae Byun et al. (2007), had studied about irradiation on packaged cooked rice. In Indonesia, Daniel (2014) showed that rendang cooked rice canned could be an alternative emergency food product with adequate acceptability and stable during the storage.

Based on several studies, the gap of the research used is expensive packaging material, namely retort pouch packaging and canned packaging. This material did not economically suitable for the emergency food product. This research aimed to develop a packaged cooked rice with nylon material packaging because nylon plastic packaging has barrier properties like gas and high temperature (Sulchan and Nur, 2007). It is suitable for vacuum packaging and good for the product in packaged food, such as instant noodle, and for sterilization products (Julianti and Nurminah, 2006). Vacuum packaging method was used in this study which reduced pressure in packaging so that $\mathrm{O}_{2}$ content in vacuum packaged food is lower than in normal packaged food (Basworo, 1998). This method can reduce contact between product and $\mathrm{O}_{2}$.

In this research, the effect of normal packaging with hand sealer and vacuum packaging with vacuum sealer toward water content, color, $\mathrm{pH}$, microbiology and acceptable consumer in different storage condition that was room temperature and cold temperature, were observed in order to evaluate the physical properties, sensory, and microbiology in the packaged cooked rice product during storage.

\section{Material and Method \\ Material}

The primary material used in this research is IR64 rice bought in Kranggan Market, Yogyakarta. Material for analysis used Plate Count Agar (Merck, Germany) and $\mathrm{NaCl}$ (Merck, Germany).

\section{Method}

\section{Production of packaged cooked rice product}

Rice was washed rice and then added with water with the ratio of water and rice 1 : 2.25. After that, rice was cooked using rice cooker (Miyako MCM-838, Indonesia) for 30 minutes. Cooked rice was packed using 100gram nylon plastic, afterwards the cooked rice was sealed using hand sealer (Double Leopard SF-200, Chinese Taipei) and the vacuum sealer (Henkeman 200 A, Netherland) with scale 5 (0.78 bar), 6 (0.86 bar), 7 (0.90 bar) and 8 (0.92 bar). It was then subjected to steaming process at $100^{\circ} \mathrm{C}$ for 45 minutes, then stored at room temperature $\left( \pm 28^{\circ} \mathrm{C}\right)$ and cold temperature $\left(4^{\circ} \mathrm{C}\right)$. Thereafter, analysis of lightness, $\mathrm{pH}$, microbiology, and sensory were performed on days 1, 4 and 7 .

\section{Lightness Analysis}

Color assessment on the ready-to-eat rice product is done by assessing the intensity of lightness ( $L$ ) on the product. This analysis was done by sampling method, using a chromameter tool (CR-400) that could bring up the parameter number " $\mathrm{L}$ " on the digital screen. The sampled part is the top, middle, and bottom. 


\section{pH Analysis}

Five gram samples were added $5 \mathrm{ml}$ of aquadest until the packaged cooked rice product could be crushed, completely homogenized and measured with $\mathrm{pH}$-meter (Crison Instruments, Spain) under room temperature.

\section{Microbiology analysis}

Colony measurement was calculated using Total Plate Count (TPC) method by FDA (1995). The homogenized sample (5 gram of sample and $45 \mathrm{~mL} \mathrm{NaCl}$ ) was diluted to a series of simple dilutions. Thereafter, $1 \mathrm{ml}$ of the last 2 dilutions were taken and then sterilized in an empty sterile petri dish and subsequently poured the medium for melting and mixing evenly by rotating the plate back and forth on the table. As the control, plate dilution was poured on agar medium. After being solidified, incubated at $37^{\circ} \mathrm{C}$ with upside-down petri dish conditions, for \pm 24 hours.

\section{Sensory Analysis}

The sensory evaluation were done by 19-20 untrained panelists. It was a preference test for several attributes i.e. aroma, texture, and taste. The assessment were done using numerical scale from 1 to 7 according to its preferences.

\section{Experimental Design}

The experimental design used completely randomized design. The analysis of variance was done using SPSS v 20.0 software at 0.05 of significancy.

\section{Result and Discussion}

\section{Lightness analysis}

From Figures 1 and Figures 2, it can be seen that the sample lightness tended to be constant for 7 days storage, except in the usual packing samples of day 1 storage of room temperature. It was most likely due to the substance decomposition by microbes which damaged the color pigment in the cooked rice, thus reduced the lightness value.

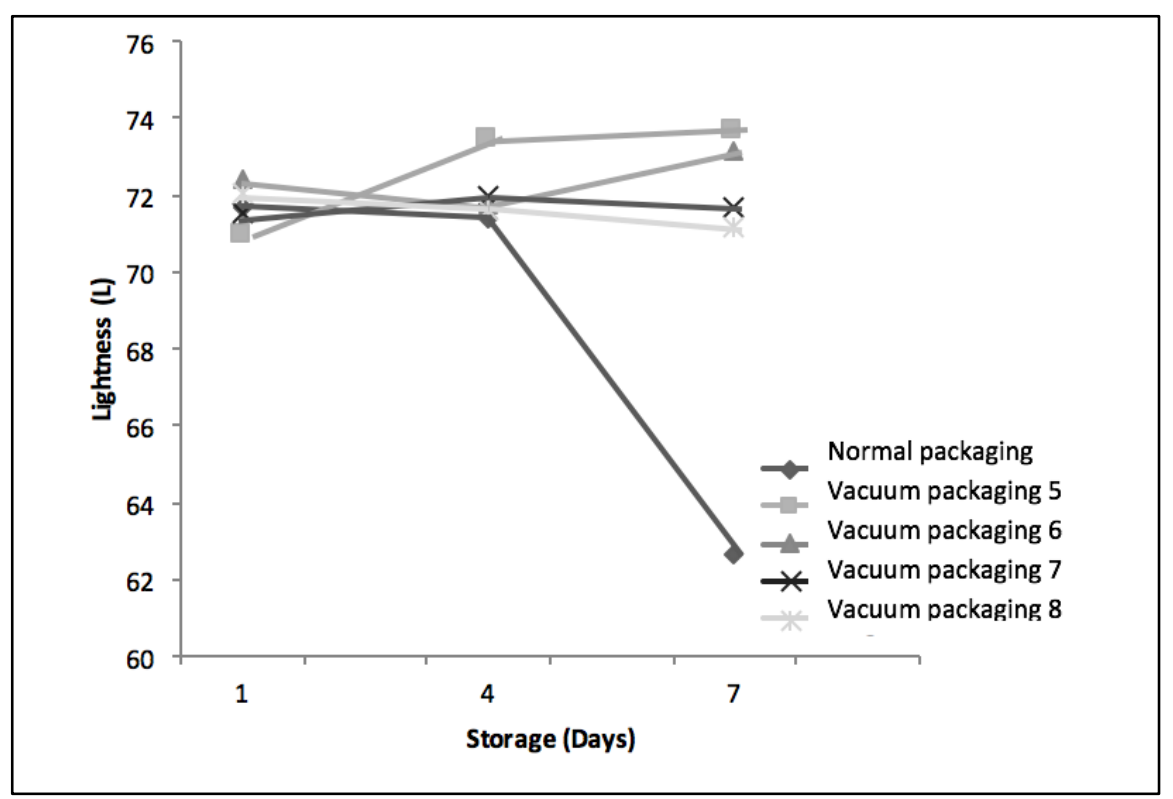

Figure 1. Lightness of the packaged cooked rice product during storage at room temperature $\left( \pm 28^{\circ} \mathrm{C}\right)$

Packaging method did not greatly affect the lightness change in cooked rice, except in the normal packaging of storage of room temperature. This was attributed to browning 
enzymatic that probably happened in cooked enzyme which responsible to this rice. Polyphenol oxidase was one of the phenomenon (Yu et al., 2017).

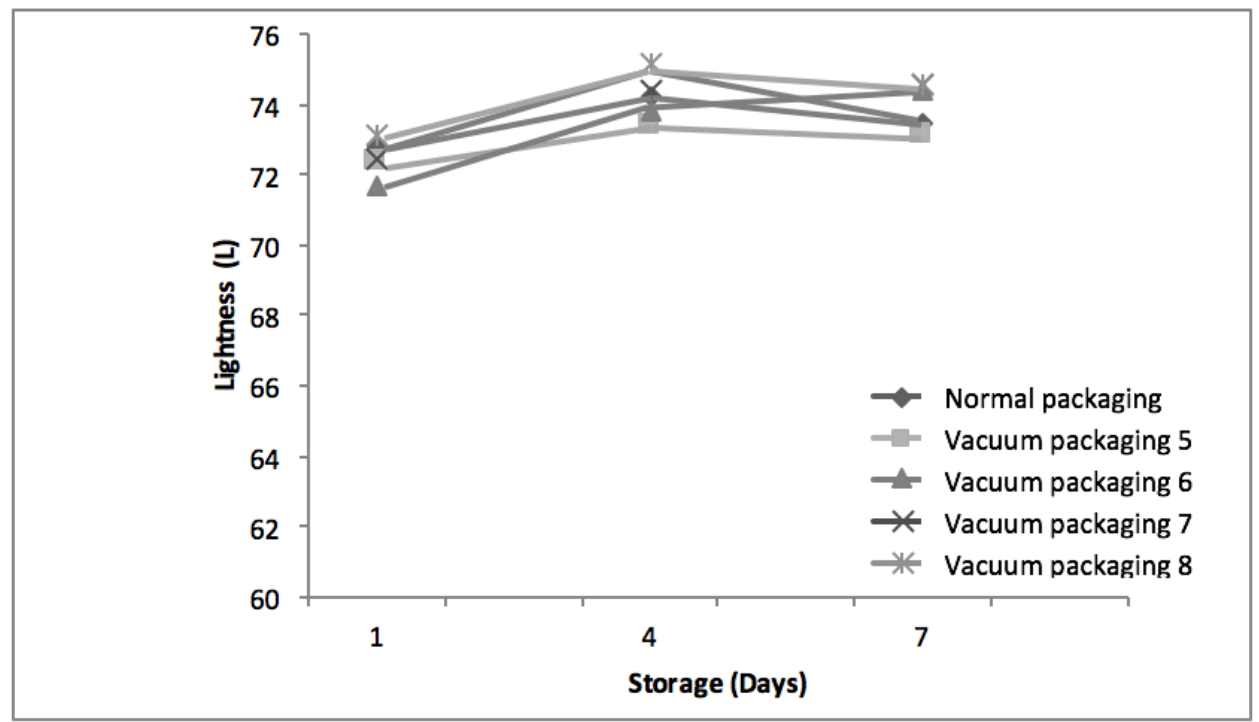

Figure 2. Lightness of the packaged cooked rice product during storage at cold temperature $\left( \pm 4^{\circ} \mathrm{C}\right)$

\section{pH analysis}

Generally, cooked rice has a neutral $\mathrm{pH}( \pm 7)$, the taste of freshly cooked rice was sweet and creamy taste. In other hand, unpleasant taste of cooked rice was sour taste as described in Gayin et al., (2009). Therefore, decreasing $\mathrm{pH}$ of cooked rice lead to the reduce of panelist's preference (Figures $\mathbf{3}$ and 4).

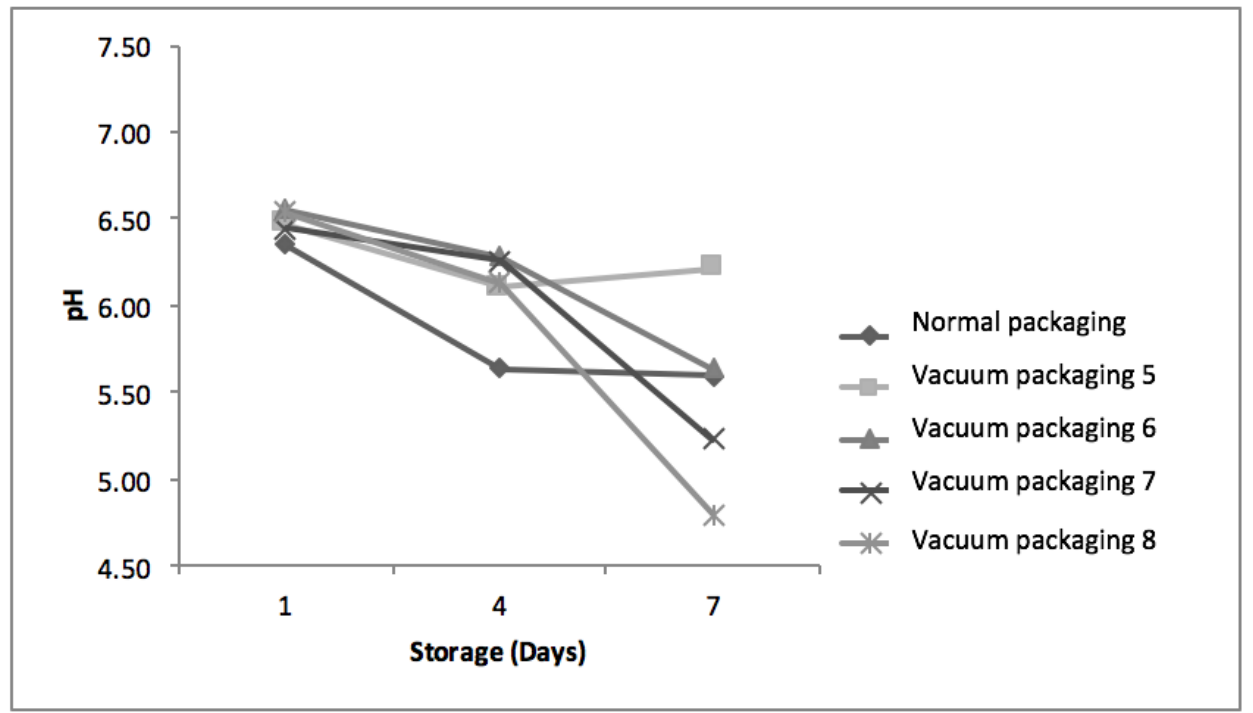

Figure 3. $\mathrm{pH}$ the packaged cooked rice product during storage at room temperature $\left( \pm 28^{\circ} \mathrm{C}\right)$

The results of storage of samples at room temperature as shown in Figure $\mathbf{3}$ showed that the $\mathrm{pH}$ of the sample decreased along with the duration of storage. At room storage, sample had an unstable $\mathrm{pH}$ due to the growth of microbial that possibly could produce acid which is probably attributed to toxin cereulide produce by microbia such as Bacillus cereus. Cereulide is a heat-stable, acid and protease-resistant cyclic peptide toxin 
that is produced in the food before ingestion. Cereulide intoxication has a short incubation time of 30 min to $6 \mathrm{~h}$, and generally lasts for 6 to $24 \mathrm{~h}$ with symptoms of nausea and vomiting. Indeed, Cereulide intoxication is highly associated with rice and rice products (Luu-Thi et al., 2014; Arnesen et al., 2008; Ehling-Schulz et al., 2006; Mahler et al., 1997).

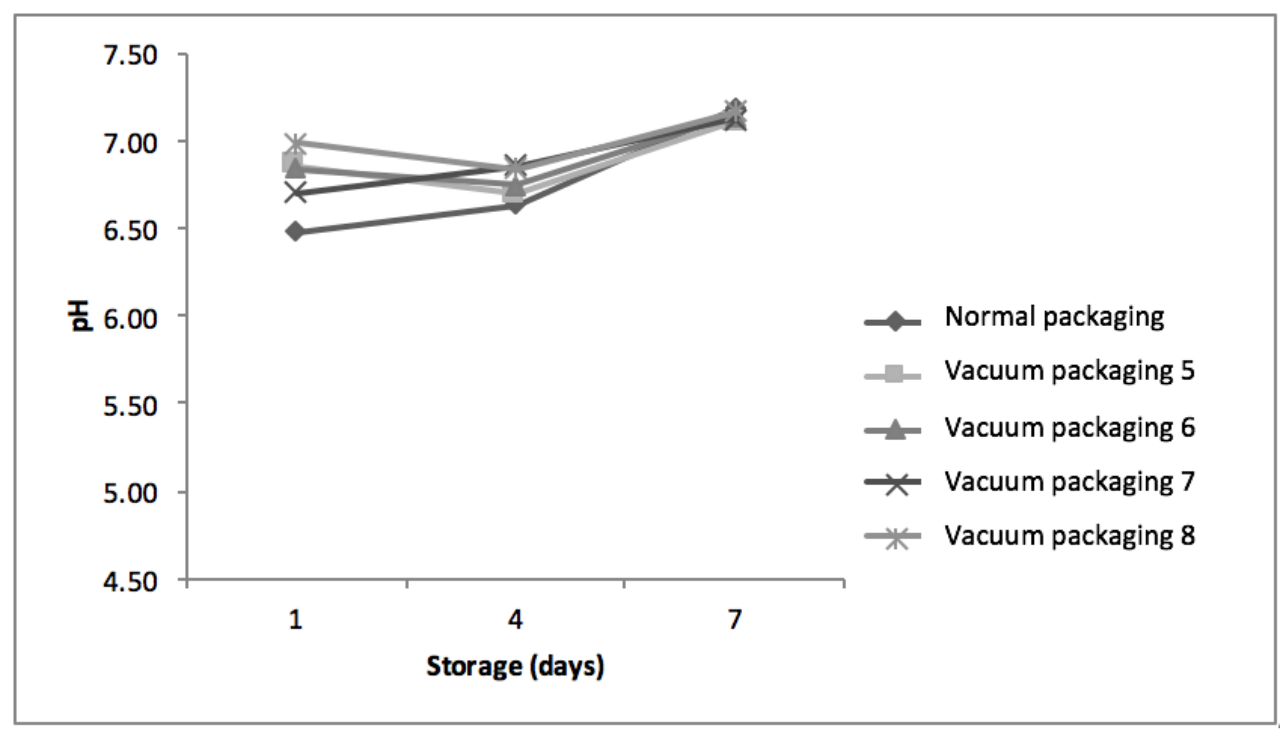

Figure 4. $\mathrm{pH}$ the packaged cooked rice product during storage at cold temperature $\left( \pm 4^{\circ} \mathrm{C}\right)$

Variations of the packaging method did not significantly affect the $\mathrm{pH}$ change of the sample during storage, especially on the variation of the vacuum packaging scale. However, in cold temperature storage shown in Figure 4, the $\mathrm{pH}$ tended to be constant, close to neutral, presumably due to constant microbial growth. In the storage sample, the room temperature (Fig. 3) had an unstable $\mathrm{pH}$ and tended to acid. This was presumably because the total microbial of storage sample, so that the acid compounds degradation became higher.

\section{Microbiology analysis}

The growth of microbial colony can be seen in Figure 5 and Figure 6 . It illustrate that the microbia grown in the sample were predominantly facultatively anaerobic microbia. This was because the packaging condition was lack of oxygen. In this condition facultatively anaerobic microbia can survive and sporulate leading to high number of microbial total in cooked rice during storage especially in room storage (Abbas et al., 2014).

From Figure 5, it can be seen that the 2 log microbial growth existed during seven days storage at room temperature. It could be caused by mesophilic microbes such as Bacillus cereus as described in Guinebretière et al., (2008) that have optimum condition for growth at room temperature. 


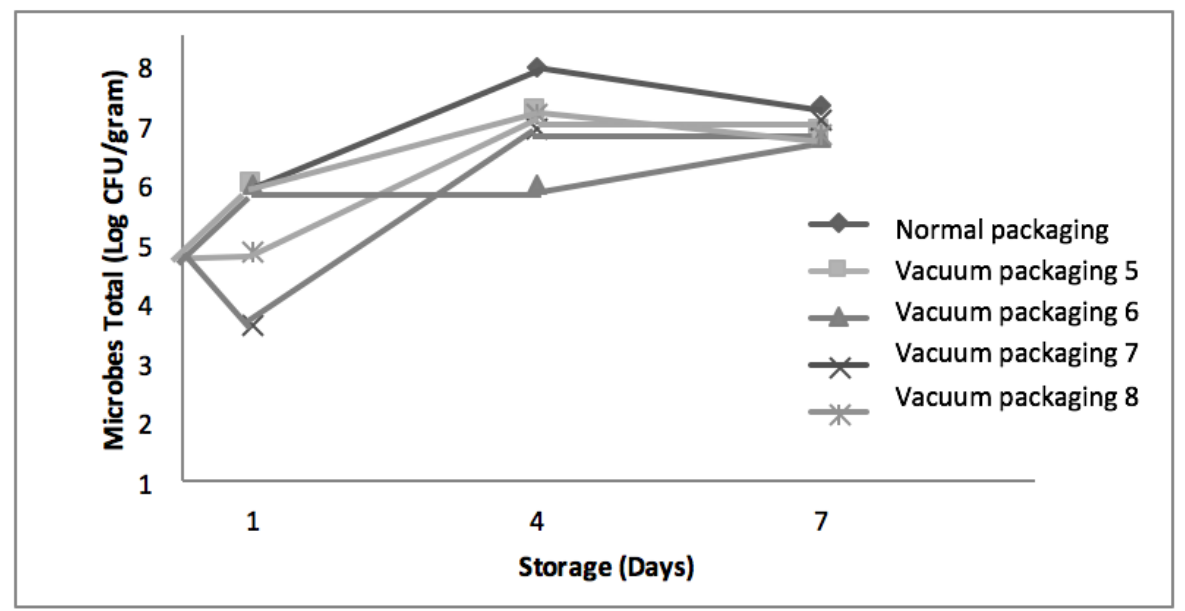

Figure 5. Microbial Total in aerobes incubation during storage at room temperature $\left( \pm 28^{\circ} \mathrm{C}\right)$

In general, the highest number of total microbial can be seen in day 4 of room storage among other storage days include day 1 and day 4 (Figure 5). According to Food and Drug Administration in Indonesia (2009) recommendation level of total microbes in cerealia food is $10^{6} \mathrm{CFU} / \mathrm{gram}$. It was predicted that on day 1 to day 4 , log phase occured in microbial and day 4 to day 7 , there was a stationary phase so the number was slightly decreased. While in the vacuum packaging samples of scale 6 and 7, the log phase occured until day 7 . Such a thing did not occur in cool storage temperature samples, so the possibility of log phase did not occur or slightly slowly-occured until day 7 .

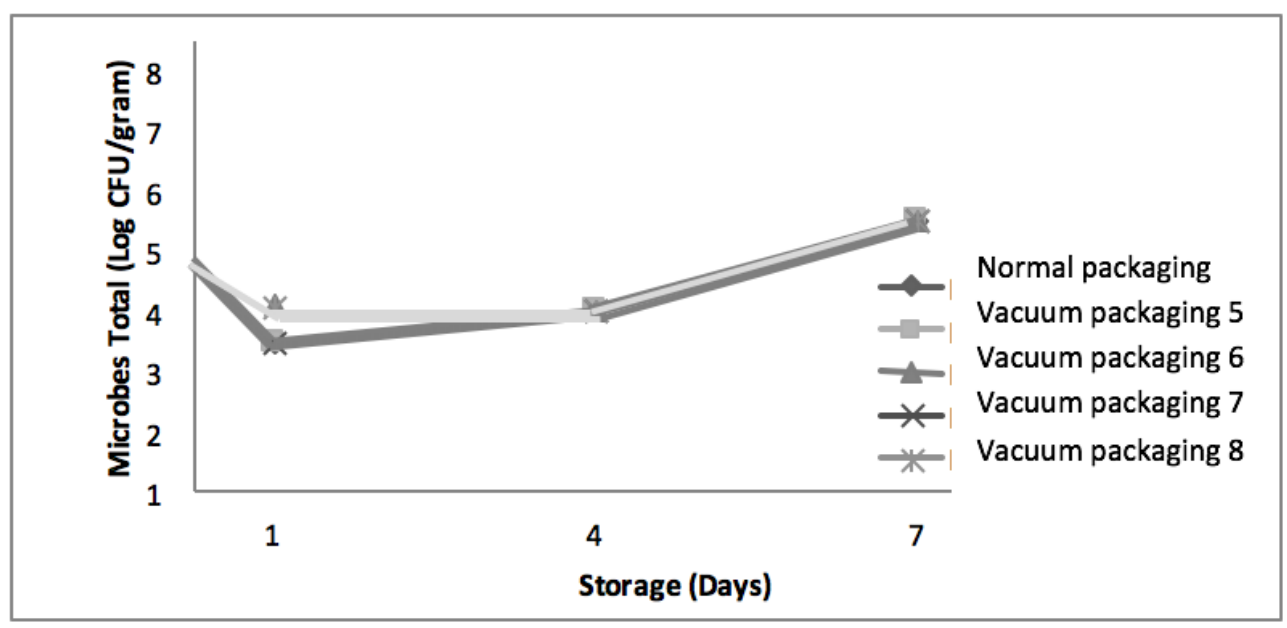

Figure 6. Microbial Total in aerobes incubation during storage at cold temperature $\left( \pm 4^{\circ} \mathrm{C}\right)$

In Figure 6, it can be seen that the total microbial decreased from the total initial microbes and gradually increased. This was attrributed to delaying microbial growth in cold temperature. The same result was reported in Ali et al., (2008) which showed that cooked rice storage in refrigerated and frozen condition can decrease total microbia in one-day-storaged cooked rice. This phenomenon can affect other analyzes, such as the constant sample color/lightness analysis (as shown in Figure 2) and the constant reflection $\mathrm{pH}$ analysis (as shown in Figure 4). 


\section{Sensory analysis}

\section{Assessment of Aroma Attributes}

In this study, sample cooked rice in day 4 and day 7 room storage can't be assessed in sensory evaluation because of unfeasible consuming. High level of propanal, pentanal, hexanal, caused by lipid oxidation in cooked rice, (Zhou et al., 2002) and microbial level beyond recommendation level $\left(10^{6}\right)$ (Frazier, 1995) were the two main reasons responsible to this phenomenon.

The results of the aroma attribute assessment in Table 1 showed that the panelists had a 'rather like' to 'normal' rating range on day 1 storage of room temperature of day 1 to day 7 cold temperature storage. It was marked with the highest score is 4.75 and the lowest score was 3.60. These results indicated that during storage, the aroma in the cooked rice was still fairly acceptable by the panelists even though the score decreased during storage. This meant that the panelist's preference decreased. It was mainly caused by the possibility of unexpected volatile compounds in rice by microbial or by chemical reactions even in small quantities such as the results shown in Figures 5 and 6 .

Table 1. Favorite Aroma Score of the packaged cooked rice product during Storage

\begin{tabular}{|c|c|c|c|c|}
\hline \multirow[b]{2}{*}{ Type of Packaging } & \multicolumn{2}{|c|}{ Storage on day 1} & \multirow{2}{*}{$\begin{array}{c}\text { Storage on day } 4 \\
\text { Cold } \\
\text { Temperature }\end{array}$} & \multirow{2}{*}{$\begin{array}{l}\text { Storage on day } 7 \\
\text { Cold Temperature }\end{array}$} \\
\hline & $\begin{array}{c}\text { Room } \\
\text { Temperature }\end{array}$ & $\begin{array}{c}\text { Cold } \\
\text { Temperature }\end{array}$ & & \\
\hline Normal Packaging & $4.15 \pm 1,14^{a}$ & $4.40 \pm 1.50^{\mathrm{a}}$ & $3.85 \pm 1.09$ & - \\
\hline Vacuum 5 Packaging & $4.40 \pm 1,23^{a}$ & $4.20 \pm 1.15^{\mathrm{a}}$ & $4.25 \pm 0.72$ & $2.35 \pm 1.18$ \\
\hline Vacuum 6 Packaging & $4.70 \pm 0.98^{a}$ & $4.70 \pm 0.86^{a}$ & $4.15 \pm 0.99$ & $2.60 \pm 1.05$ \\
\hline Vacuum 7 Packaging & $4.25 \pm 1.45^{\mathrm{a}}$ & $4.75 \pm 1.16^{\mathrm{a}}$ & $4.45 \pm 1.10$ & $3.00 \pm 1.34$ \\
\hline Vacuum 8 Packaging & $4.65 \pm 0.88^{a}$ & $4.70 \pm 0.86^{a}$ & $4.20 \pm 1.06$ & $2.95 \pm 1.47$ \\
\hline
\end{tabular}

Score 1 = Very unlike; 2 = unlike; 3 = rather unlike; 4 = cursory; 5 = rather like; 6 = like; 7 = very like

\section{Assessment of Texture Attributes}

Room-storaged cooked rice texture had been damaged (soft), so it was not feasible to be presented to the panelist and to the possibility of the high microbial activity as shown in Figure 5 could be a health damage so this was not presented.The texture of the rice was usually assessed from the level of hardness (pera) on the cooked rice. More hardness of cooked rice, more unlike by panelist.. However there were some people who liked hard rice (pera). The results in Table $\mathbf{2}$ indicated that the texture of the sample was not particularly favorable, especially in cold storage day 7. Most likely because during storage of cold temperatures, starch in rice was retrograded so the rice became hard and the panelists were less fond of hard rice. Thus, the texture of packed rice during storage appeared to be less acceptable to the panelist or the acceptance level was low in terms of texture. 
Table 2. Texture Favorite Score of the ready-to-eat cooked rice product during Storage

\begin{tabular}{ccccc}
\hline & \multicolumn{2}{c}{ Storage on day 1} & Storage on day 4 & Storage on day 7 \\
\cline { 2 - 5 } Type of Packaging & Room & Cold & Cold Temperature & Cold Temperature \\
& Temperature & Temperature & & \\
\hline Normal Packaging & $3.60 \pm 1.43^{\mathrm{a}}$ & $3.50 \pm 1.67^{\mathrm{a}}$ & $3.15 \pm 1.09$ & - \\
Vacuum 5 & $4.75 \pm 1.25^{\mathrm{b}}$ & $4.40 \pm 1.79^{\mathrm{a}}$ & $3.65 \pm 1.18$ & $2.00 \pm 1.08$ \\
Packaging & & & & $2.20 \pm 1.01$ \\
Vacuum 6 & $4.15 \pm 1.76^{\mathrm{ab}}$ & $4.15 \pm 1.35^{\mathrm{a}}$ & $2.95 \pm 1.10$ & \\
Packaging & & & $3.30 \pm 1.34$ & $2.45 \pm 1.32$ \\
Vacuum 7 & $3.75 \pm 1.77^{\mathrm{ab}}$ & $3.65 \pm 1.39^{\mathrm{a}}$ & & \\
Packaging & & & $3.25 \pm 1.12$ & $2.45 \pm 1.50$ \\
Vacuum 8 & $4.05 \pm 1.57^{\mathrm{ab}}$ & $3.55 \pm 1.36^{\mathrm{a}}$ & & \\
Packaging & & & & \\
\hline
\end{tabular}

Score 1 = Very unlike; 2 = unlike; 3 = rather unlike; 4 = cursory; 5 = rather like; 6 = like; 7 = very like

\section{Assessment of Taste Attributes}

Taste of cooked rice are usually neutral and nothing strange. If there is something abnormal to the cooked rice, then there is a strange taste that arises in the cooked rice. In Table 3, the panelists assessed the taste attributes of 'dislikes' to 'somewhat dislikes' and their favorite levels decreased with length of storage. This was due to the possibility of the compound appearance in cooked rice that may interfere the taste preference by the panelists, such as the improvement of acidic $\mathrm{pH}$ as shown in Figure 3. This was mainly because of the high microbial activity (Figure 5). However, the overall attribute of taste to packed rice was still slightly acceptable by panelists although the acceptance rate was lower than in the aroma attributes in the cooked rice.

Table 3. Favorite Taste Score of the ready-to-eat cooked rice product during Storage

\begin{tabular}{|c|c|c|c|c|}
\hline \multirow[b]{2}{*}{ Type of Packaging } & \multicolumn{2}{|c|}{ Storage on day 1} & \multirow{2}{*}{$\begin{array}{l}\text { Storage on day } 4 \\
\text { Cold Temperature }\end{array}$} & \multirow{2}{*}{$\begin{array}{l}\text { Storage on day } 7 \\
\text { Cold Temperature }\end{array}$} \\
\hline & $\begin{array}{c}\text { Room } \\
\text { Temperature }\end{array}$ & $\begin{array}{c}\text { Cold } \\
\text { Temperature }\end{array}$ & & \\
\hline Normal Packaging & - & - & - & - \\
\hline $\begin{array}{l}\text { Vacuum } 5 \\
\text { Packaging }\end{array}$ & $4.55 \pm 1.23^{a b}$ & $4.50 \pm 1.40^{b}$ & $3.75 \pm 0.97$ & $2.00 \pm 1.08$ \\
\hline $\begin{array}{l}\text { Vacuum } 6 \\
\text { Packaging }\end{array}$ & $4.55 \pm 1.28^{\mathrm{ab}}$ & $4.10 \pm 1.29^{a b}$ & $3.65 \pm 0.81$ & $2.20 \pm 1.01$ \\
\hline $\begin{array}{l}\text { Vacuum } 7 \\
\text { Packaging }\end{array}$ & $3.85 \pm 1.63^{a}$ & $3.95 \pm 1.10^{\mathrm{ab}}$ & $3.80 \pm 1.11$ & $2.45 \pm 1.32$ \\
\hline
\end{tabular}


Vacuum 8

Packaging

$$
4.75 \pm 1.21^{b}
$$

$3.45+1.90^{a}$

$3.45+1.10$

$2.45+1.50$

Score 1 = Very unlike; 2 = unlike; 3 = rather unlike; 4 = cursory; 5 = rather like; 6 = like; 7 = very like

\section{Conclusion}

From the results, it can be concluded that the appropriate packaging method for making the ready-to-eat cooked rice product is vacuum sealing. The ready-to-eat cooked rice product has a rapid deterioration in physical properties and microbiological quality if the packaging was carried out by hand sealing packaging method at room temperature storage compared with vacuum sealing packaging method at the same storage temperature. As for storage at cold temperatures did not give a significant effect, but the results were better than the storage room temperature.

\section{References}

Abbas, Amina Aicha, Stella Planchon, Michel Jobin, and Philippe Schmitt. 2014. "Absence of Oxygen Affects the Capacity to Sporulate and the Spore Properties of Bacillus Cereus." Food Microbiology 42: 122-31. http://dx.doi.org/10.1016/j.fm.2014.03 .004.

Ali, MA, AMK Hasan, and MN Islam. 2008. "Study on the Period of Acceptability of Cooked Rice." Journal of the Bangladesh Agricultural University 6(2): 401-8.

http://www.banglajol.info/index.php/J BAU/article/view/4840.Arnesen, L.P.S., Fagerlund, A., Granum, P.E., 2008. From soil to gut: Bacillus cereus and its food poisoning toxins. FEMS Microbiol. Rev. 32, 579-606.

Association of Indonesian Environmental Observers. (2015). "Geographical Location of Indonesia". In http://www.hpli.org/bencana.php. Retrieve on April 10, 2015 at 21:02 pm.
Food and Drug Administration. 1995. Bacteriological Analytical Manual: Aerobic Plate Count. Silver Spring, U.S.A.

Basworo, R. 1998. Effect of vacuum packaging on quality of sale pisang. Thesis. Department of Food and Agricultural Product Technology Faculty of Agricultural Technology, Gadjah Mada University, Yogyakarta.

Billiris, M. A., Siebenmorgen, T. J., Meullenet, J. F., \& Mauromoustakos, A. 2012. Rice degree of milling effects on hydration, texture, sensory and energy characteristics. Part 1. Cooking using excess water. Journal of Food Engineering, 113(4), 559-568. https://doi.org/10.1016/j.jfoodeng.201 2.07.005

Byun, Y., Hong, S. I., Mangalassary, S., Bae, H. J., Cooksey, K., Park, H. J., \& Whiteside, S. 2010. The performance of organic and inorganic coated retort pouch materials on the shelf life of ready-toeat rice products. $L W T$ - Food Science and Technology, 43(6), 862-866. https://doi.org/10.1016/j.Iwt.2010.01. $\underline{009}$

Chorin, Eric, Dominique Thuault, Jean Jacques Cléret, and Claude Marcel Bourgeois. 1997. "Modelling Bacillus Cereus Growth." International Journal of Food Microbiology 38(2-3): 229-34.

Daniel. 2014. Rendang Tin Rice: Evaluation of Microbiology, Chemistry, and Organoleptic. Thesis. Department of Food and Agricultural Product Technology Faculty of Agricultural Technology, Gadjah Mada University, Yogyakarta. 
Ehling-Schulz, M., Guinebretière, M.-H., Monthán, A., Berge, O., Fricker, M., Svensson, $\quad$ B., 2006. Toxin gene profiling of enterotoxin and emetic Bacillus cereus. FEMS

Microbiol.

Lett. 260, 232-240

Food and Drug Administration in Indonesia. 2009. Batas Maksimal Cemaran Mikrobia dan Kimia dalam Makanan. Indonesia

Frazier, W.C. and Westhoff, D.C. 1995. Food Microbiology. 4th ed. and 28th reprint 2007. Tata McGraw-Hill Pub. Co. Ltd. New Delhi. P- 54, 508

Gaffar, Z. 2015. Statistics of Disaster Events in Indonesia.

\section{In} http://www.penetulangankrisis.depkes. go.id/statistik-kejadian-bencana-tahun2014. Retrieve on 10 April 2015 at 20:58 pm

Gayin, J., J. T. Manful, and P. N T Johnson. 2009. "Rheological and Sensory Properties of Rice Varieties from Improvement Programmes in Ghana." International Food Research Journal 16(2): 167-74.Julianti, E. and Nurminah M. (2006). "Packaging Technology". Faculty of Agriculture, North Sumatra University, North Sumatra.

Guinebretière, M.-H.,Thompson, F.L.,Sorokin, A., Normand, P.,Dawyndt, P.,EhlingSchulz, M.,Svensson, B.,Sanchis, V.,Nguyen-The, C.,Heyndrickx, M.,De Vos, P., 2008. Ecological diversification in the Bacillus cereus group. Environ. Microbiol. 10, 851-865

Lee, K. W. (2006). Market trends of instantt rice and instant porridge. Food World. 7. Luu-Thi, H., Khadka, D.B., and Michiels, C.W. 2014. Thermal inactivation parameters of spores from different phylogenetic groups of Bacillus cereus. International Journal of Food Microbiology 189 183188.
Mahler, H.,Pasi, A.,Kramer, J.M.,Schulte, P.,Scoging, A.C.,Bar, W.,Krahenbuhl, S., 1997. Fulminant liver failure in association with the emetic toxin of Bacillus cereus. N. Engl. J. Med. 336, 1142-1148

Marsudi, F. 1984. Evaluation Characteristics Cooked Rice "Quick Cooked Rice" From Several Variety of Rice. Thesis. Department of Food and Agricultural Product Technology Faculty of Agricultural Technology, Gadjah Mada University, Yogyakarta.

National Coordination Agency. 2002. "Direction of Urban Disaster Mitigation Policy in Indonesia". Jakarta: National Coordination Agency.

Jae Byun, Y., Hong, S. I., Kim, K. B., Jeon, D. H., Kim, J. M., Whiteside, W. S., \& Jin Park, H. 2007. Physical and chemical properties of $\gamma$-irradiated EVOH film. Radiation Physics and Chemistry, 76(6), 974-981.

https://doi.org/10.1016/j.radphyschem .2006.09.005

Sari, D., Sirajuddin, S., \& Hendrayati. 2012. Pengaruh Lama Pemanasan Dalam Rice Cooker Terhadap Kandungan Zat Besi (Fe) Dan Total Mikroba Nasi Putih. Media Gizi Masyarakat Indonesia, 2(1), 22-26.

Sulchan, M. and Nur E. 2007. Food Safety of Plastic and Styrofoam Packaging. Faculty of Medicine, Diponegoro University, Semarang.

Winarno, F. G. 1992. Food Chemistry and Nutrition. Jakarta: Gramedia Pustaka Utama.

Yu, L. et al. 2017. "Review of the Effects of Different Processing Technologies on Cooked and Convenience Rice Quality." Trends in Food Science and Technology 59: 124-38.

Zhou, Z., K. Robards, S. Helliwell, and C. Blanchard. 2002. "Ageing of Stored 
Rice: Changes in Chemical and Physical 35(1):

$65-78$.

Attributes." Journal of Cereal Science 
